\title{
A Study of the Co-movement and Spillover Effects of Stock Markets Among China and ASEAN-5 Countries
}

\author{
Yi-Ming $\mathrm{Li}^{1{ }^{1, *}} \mathrm{Li}-\mathrm{Ru} \mathrm{Bai}^{1}$ \\ ${ }^{1}$ Emerging Economic Formats Research Institute, Shandong Management University, Jinan, Shandong, China \\ *Corresponding author. Email: kevin050590@ hotmail.com
}

\begin{abstract}
China and southeast Asian countries are geographically close and have strong economic ties for a long time. In recent years, China and the Association of Southeast Asian Nations (ASEAN) countries have gradually opened their markets and strengthened their economic and trade links, reflected in their capital markets. This paper tends to explore the characteristics of stock markets between China and the ASEAN-5 countries in the long-term and short-term. The empirical results show that the co-movement between China and the ASEAN-5 countries is not significant in the long run, while the mean spillover effect and volatility spillover effect are significant in the short run, which reflects the close financial ties between China and the ASEAN-5 countries. Therefore, preventive actions ought to be taken to defend themselves from the transmission of regional financial risks by authorities. Meanwhile, cooperation between neighbouring countries should be strengthened to cope with systemic financial risk.
\end{abstract}

Keywords: ASEAN-5, Mean Spillover, Volatility Spillover, Co-movement

\section{INTRODUCTION}

For the recent 40 years of reform and opening up, China has experienced high economic growth rate. The capital markets connection between China and the other countries has gradually become a hot issue. The Association of Southeast Asian Nations (ASEAN), established on August 8, 1967 in Bangkok, has 10 member states, namely Brunei, Cambodia, Indonesia, Laos, Malaysia, Myanmar, the Philippines, Singapore, Thailand and Vietnam. ASEAN and China are geographically adjacent, and have a long history of economic and cultural exchanges. On September 5, 2013, president Xi put forward the One Belt One Road initiative to deepen the cooperation with relative countries. Under this initiative, China and ASEAN countries will continue to promote the connectivity and strengthen economic ties. In addition, with the open regionalism of ASEAN countries and the establishment of China-ASEAN free Trade Area, the economic linkage among China and ASEAN countries has been further enhanced.

This paper will research the co-movement of capital market among China and the ASEAN members to reflect the economic linkage characteristic in the long run, to explore whether there is a long-term equilibrium relationship among the stock markets. In the short term, this paper will focus on spillover effects of ChinaASEAN stock markets, by examining how they influence each other. It is of great significance to study the stock market co-movement and spillover effect among China and the ASEAN countries, to ascertain whether bilateral volatility spillover will cause regional financial turbulence. Also, the study is ecologically important to effectively prevent the spread of financial risks, to strengthen the regulatory cooperation of regional investment and trade, to protect the interests of investors.

\section{LITERATURE REVIEW}

There have been a lot of researches about the comovement and spillover effects on the stock markets among ASEAN countries and China. Lean and Smyth (2014) found that a long-term co-integration relationship, among A-shares and the stock indexes of Singapore, the Philippines, Vietnam, Malaysia, Indonesia and Thailand, does exist. Also, financial risks were contagious to some extent, but the impact was weak. ${ }^{[1]}$ Kee et al. (2014) discovered that the spillover effect among China and ASEAN countries is inconspicuous, while economic activities of ASEAN countries have spillover effect on China's stock market, based on DCC-GARCH model and VAR model. ${ }^{[2]}$ 
In addition, some major economic events, such as reform or external financial shocks, will affect the stock market correlation among the stock markets. Li Ning and Li Gang (2011) believe that a long-term stock market relationship among China and the Philippines, Korea as well as Singapore was enhanced after the split share structure reform, which was weak before. ${ }^{[3]} \mathrm{Li}$ Nan (2016) built the DCC-GARCH model to find that, before and after the financial crisis, the stock market synchronization among the United States and ASEAN countries declined, while that among China and ASEAN countries began to rise. ${ }^{[4]} \mathrm{Cai}$ Xing and $\mathrm{Li}$ Xiaohao (2019) believe that RMB internationalization will enhance the dynamic convergence among the stock markets of China and the ASEAN countries. ${ }^{[5]}$

Most of the discussions focus on the linkage of stock indexes instead of the spillover effect, which is not studied separately into mean spillover effect and volatility spillover effect. Hence, in this paper, it will study the trend of synergic changes among stock markets of China and ASEAN countries from a longterm perspective, using the co-integration model to describe it. Furthermore, the short-term spillover effect will be analyzed with VAR model and GARCH model, which are respectively used to study the mean spillover effect and volatility spillover effect among stock markets.

\section{EMPIRICAL ANALYSIS}

Stock index is a significant description of a country , s stock market, representing its trend and characteristics. The most representative stock index of China is the CSI300, which is composed of the 300 largest stocks by market capitalization in Shanghai and Shenzhen stock exchanges and basically covers all blue chip stocks. Five countries of ASEAN, with high levels of economic development are selected, which are Malaysia, Singapore, the Philippines, Thailand and Indonesia. The MSCI-Malaysia Index (MSM), the MSCI-Singapore Index (MSS), the PSE Composite Index (PSI), The Stock Exchange of Thailand (SET) and Indonesia Jakarta Stock Exchange (ISE) respectively selected to represent the ASEAN-5 stock markets. In this paper, the daily closing prices of the stock index from July 9, 2010 to August 4, 2020 are selected as samples. Excluding the days when not all six markets are open, 1623 observations remains. The data come from the Wind database.

\subsection{Statistical Description}

Firstly, the closing prices of the stock index are statistically described in Table 1 . In addition, in order to explore the statistical features of daily return, the stock return of six markets are defined as $\mathrm{RCSI}=\operatorname{lnCSI}_{\mathrm{t}^{-}}$ $\operatorname{lnCSI} \mathrm{I}_{\mathrm{t}-1}, \quad \mathrm{RMSM}=\operatorname{lnMSM}_{\mathrm{t}^{-}} \operatorname{lnMSM}_{\mathrm{t}-1}, \quad \mathrm{RMSS}=$

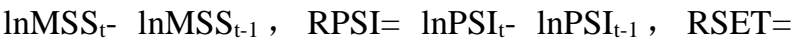
$\operatorname{lnSET}_{\mathrm{t}}-\operatorname{lnSET} \mathrm{T}_{\mathrm{t}-1}$ and RISE $=\ln \mathrm{nSE}_{\mathrm{t}}-\operatorname{lnISE} \mathrm{t}_{\mathrm{t}-1}$, statistically described in Table 2.

Table 1. Descriptive statistics of China and ASEAN-5 stock index

\begin{tabular}{|l|l|l|l|l|l|}
\hline Variables & Mean & Std. Dev & Skewness & Kurtosis & $\begin{array}{l}\text { Jarque- } \\
\text { Bera }\end{array}$ \\
\hline CSI & 3279.777 & 708.7943 & -0.030993 & 2.267127 & $36.58142^{* *}$ \\
\hline MSM & 597.690 & 41.46915 & -0.778643 & 4.321540 & $282.1048^{* *}$ \\
\hline MSS & 1656.749 & 128.8148 & -0.660075 & 3.011920 & $117.8663^{* *}$ \\
\hline PSI & 7160.490 & 833.0145 & -0.580527 & 2.800215 & $93.86094^{* *}$ \\
\hline SET & 1510.288 & 151.1020 & -0.210343 & 2.620925 & $21.68557^{* *}$ \\
\hline ISE & 5278.706 & 708.4143 & 0.151415 & 1.840140 & $97.17582^{* *}$ \\
\hline
\end{tabular}

$*$ denotes rejection of the hypothesis at the $5 \%$ level

** denotes rejection of the hypothesis at the $1 \%$ level

It can be seen from the table above that the Philippines has the highest average closing price and the largest standard deviation. On the contrary, Malaysia has the lowest mean value and the lowest variance, indicating that there is difference among the stock prices of the six markets, so as the volatility. Furthermore, according to the results of Jarque-Bera statistics, the null hypothesis that the distribution of stock prices is normal distribution is rejected in all markets, which can be also detected from the Skewness and Kurtosis.

Table 2. Descriptive statistics of China and ASEAN-5 stock returns

\begin{tabular}{|l|l|l|l|l|l|}
\hline Variables & Mean & Std. Dev & Skewness & Kurtosis & Jarque-Bera \\
\hline RCSI & -0.102671 & 1.302908 & 0.338210 & 8.196790 & $1857.264 *$ \\
\hline RMSM & -0.007121 & 0.596313 & 0.040716 & 19.05421 & $17429.96^{* *}$ \\
\hline RMSS & 0.037861 & 0.682904 & 0.854883 & 12.25925 & $5995.433^{* *}$ \\
\hline RPSI & 0.005449 & 1.036383 & 0.273961 & 10.14363 & $3471.308^{* *}$ \\
\hline RSET & 0.056505 & 0.807914 & -1.250117 & 30.76991 & $52572.96^{* *}$ \\
\hline RISE & 0.007790 & 0.906608 & -0.230775 & 14.95870 & $9685.499^{* *}$ \\
* denotes rejection of the hypothesis at the 5\% level \\
** denotes rejection of the hypothesis at the 1\% level \\
From the perspective of stock returns, the average
\end{tabular}

daily yield of Thailand is the highest one, followed by Singapore, Indonesia and the Philippines, while the average daily yield of China and Malaysia is negative. Meanwhile, relatively sharp fluctuations of stock returns are shown in China stock market. Similarly, the distribution of the six stock returns is also significantly different from the normal distribution and has an obvious peak and fat tails, among which Thailand has the most remarkable bulge. Skewness varies in different countries. Generally speaking, mature capital markets, such as that of Thailand and Indonesia, are deflecting to left, while less-developed capital markets are deflecting to right.

\subsection{Unit Root Test}

The stationarity test is the premise to study the longterm relationship of the stock market, namely the co- 
integration relationship. In this paper, ADF model is adopted to conduct unit root test on the daily stock returns, and the lag order and model type are determined according to SC criterion. As shown in Table 3, the null hypothesis that stock returns have one unit root are significantly rejected at the $1 \%$ level and all sequences are stationary, so the co-integration test can be performed.

Table 3. Unit root test results of stock returns

\begin{tabular}{|l|l|l|l|l|l|}
\hline Variables & $(\mathrm{C}, \mathrm{T}, \mathrm{L})$ & T-statistics & $1 \%$ Critical Value & $5 \%$ Critical Value & $10 \%$ Critical Value \\
\hline RCSI & $(0,0,1)$ & $-40.51711 * *$ & -3.963711 & -3.412582 & -3.128252 \\
\hline RMSM & $(0,0,2)$ & $-23.01072 * *$ & -3.963718 & -3.412586 & -3.128254 \\
\hline RMSS & $(0,0,1)$ & $-28.08396 * *$ & -3.963715 & -3.412584 & -3.128253 \\
\hline RPSI & $(0,0,1)$ & $-41.83859 * *$ & -2.566388 & -1.941019 & -1.616568 \\
\hline RSET & $(0,0,1)$ & $-32.68852 * *$ & -2.566389 & -1.941019 & -1.616568 \\
\hline RISE & $(0,0,4)$ & $-20.64979 * *$ & -3.963725 & -3.412589 & -3.128256 \\
\hline
\end{tabular}

* denotes rejection of the hypothesis at the $5 \%$ level

** denotes rejection of the hypothesis at the $1 \%$ level

\subsection{Co-integration Test}

Table 4. Johansen co-integration test results of stock returns

\begin{tabular}{|l|l|l|l|l|}
\hline $\begin{array}{l}\text { Null } \\
\text { Hypothesis }\end{array}$ & Eigenvalue & $\begin{array}{l}\text { Trace } \\
\text { Statistic }\end{array}$ & $\begin{array}{l}5 \% \\
\text { Critical } \\
\text { Value }\end{array}$ & Prob. \\
\hline $\mathrm{r}=0$ & 0.227652 & 2065.24 & 95.7537 & 1.0000 \\
\hline $\mathrm{r}=1$ & 0.214579 & 1647.28 & 69.8189 & 1.0000 \\
\hline $\mathrm{r}=2$ & 0.201876 & 1256.48 & 47.8561 & 1.0000 \\
\hline $\mathrm{r}=3$ & 0.181542 & 891.630 & 29.7971 & 0.0001 \\
\hline $\mathrm{r}=4$ & 0.177559 & 567.490 & 15.4947 & 0.0001 \\
\hline $\mathrm{r}=5$ & 0.143805 & 251.206 & 3.84147 & 0.0000 \\
\hline
\end{tabular}

Among the stock markets of China and the ASEAN5 countries, if two or more show a common trend of change, they have a co-integration relationship. In this paper, the Johansen model is selected to study whether there is a long-term equilibrium relationship among the six stock returns. The results are shown in Table 4 , in which the null hypothesis that there is no co-integration relationship is accepted. Therefore, if we take stock markets of China and the ASEAN-5 countries as a whole, there is no long-term equilibrium relationship among them. As China and ASEAN are geographically and economically close, there should be a co-integration relationship. External shocks may be the cause. According to the research of Dooley and Hutchison (2009), external shocks such as economic crisis are likely to affect the co-integration relationship and sometimes make it disappear. Under the influence of the subprime crisis in 2008 and the European debt crisis in
2009, the global stock market correlations tend to be statistically insignificant. ${ }^{[6]}$

\subsection{Mean Spillover Effect Analysis}

According to the previous analysis, stock returns of China and the ASEAN-5 countries are stationary but there is no long-term co-integration relationship among them. However, in the short term, the interaction among stock markets are defined as spillover relationship, which can be divided into mean spillover effect and volatility spillover effect. Firstly, this paper researches the mean spillover effect by means of VAR model. Based on the information criterion, the VAR model is built with the lag order of 4 . On that basis, Granger causality test, impulse response analysis and variance decomposition are carried out respectively.

\subsubsection{Granger Causality Test}

In order to visually show the influencing relationship among the various markets, the Granger causality test results of stock returns in China and ASEAN-5 counties in Table 5 are visualized to denotation of graphic in Figure 1. As shown, at the 5\% significance level, neither Indonesia nor Singapore will be affected by other countries, but both of them make influence on the Philippines, China and Thailand. In addition, Thailand stock market also has an impact on China stock market. Both the Philippines and China are only being affected, having no effect on other countries. Also, the influencing paths among China and the ASEAN-5 countries are basically one-way rather than two-way relationship.

Table 5. Granger causality test results of stock returns

\begin{tabular}{|l|l|l|l|}
\hline Null Hypothesis & F-Statistic & Prob. \\
\hline \multirow{4}{*}{ RCSI does not Granger Cause: } & RMSM & 0.42548 & 0.5143 \\
\cline { 2 - 4 } & RMSS & 1.26819 & 0.2603 \\
\cline { 2 - 4 } & RPSI & 1.75525 & 0.1854 \\
\cline { 2 - 4 } & RSET & 0.91320 & 0.3394 \\
\cline { 2 - 4 } & RISE & 0.02532 & 0.8736 \\
\hline
\end{tabular}




\begin{tabular}{|l|l|l|l|}
\hline \multirow{5}{*}{ RMSM does not Granger Cause: } & RCSI & 0.82067 & 0.3651 \\
\cline { 2 - 4 } & RMSS & 1.78979 & 0.1811 \\
\cline { 2 - 4 } & RPSI & 25.5253 & 0.0000 \\
\cline { 2 - 4 } & RSET & 0.27000 & 0.6034 \\
\cline { 2 - 4 } & RISE & 0.17816 & 0.6730 \\
\hline \multirow{5}{*}{ RMSS does not Granger Cause: } & RCSI & 6.17079 & 0.0131 \\
\cline { 2 - 4 } & RMSM & 2.66173 & 0.1030 \\
\cline { 2 - 4 } & RPSI & 24.0955 & 0.0000 \\
\cline { 2 - 4 } & RSET & 6.08192 & 0.0138 \\
\cline { 2 - 4 } & RISE & 0.06506 & 0.7987 \\
\hline \multirow{5}{*}{ RSSI does not Granger Cause: } & RCSI & 2.03307 & 0.1541 \\
\cline { 2 - 4 } & RMSM & 0.32014 & 0.5716 \\
\cline { 2 - 4 } & RMSS & 0.90490 & 0.3416 \\
\cline { 2 - 4 } & RSET & 21.0238 & 0.0000 \\
\cline { 2 - 4 } & RISE & 0.99660 & 0.3183 \\
\hline \multirow{5}{*}{ RISE does not Granger Cause: } & RCSI & 14.5995 & 0.0001 \\
\cline { 2 - 4 } & RMSM & 0.83824 & 0.3600 \\
\cline { 2 - 4 } & RMSS & 0.76699 & 0.3813 \\
\cline { 2 - 4 } & RPSI & 2.60201 & 0.1069 \\
\cline { 2 - 4 } & RISE & 0.20496 & 0.6508 \\
\hline & RCSI & 3.99428 & 0.0458 \\
\cline { 2 - 4 } & RMSM & 0.00378 & 0.9510 \\
\cline { 2 - 4 } & RMSS & 0.50962 & 0.4754 \\
\cline { 2 - 4 } & RPSI & 7.51427 & 0.0062 \\
\hline & RSET & 0.5052 \\
\hline
\end{tabular}

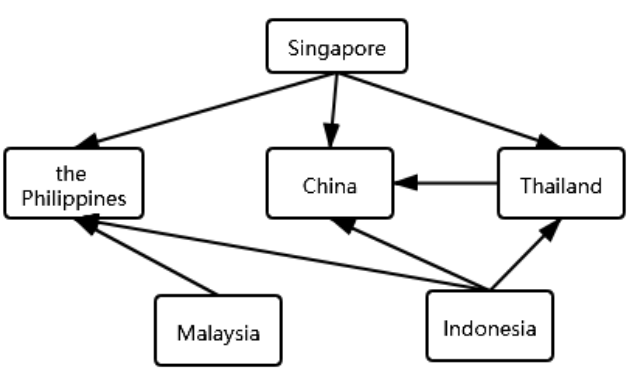

Figure 1 Causality of China and ASEAN-5 stock returns.

\subsubsection{Impulse Response Analysis}

The impulse response analysis can show how the impact on one endogenous variable will affect other endogenous variables. As shown in Figure 2, the abscissa axis represents ten periods in which the China stock market will respond to the foreign impulses, while the vertical axis represents the variety of the returns on the China stock market. It reveals the stock returns in
China will respond significantly to external economic shocks from the ASEAN-5 countries stock returns respectively in the following four periods and reached its maximum in the second period. For China, the Philippines is the biggest influencing factor, followed by the Singapore, and the changes of two markets are in the same direction. The China stock returns respond oppositely to the shock from Malaysia, Indonesia and Thailand.

\subsubsection{Variance Decomposition}

When the structural impact occurs, the change of each endogenous variable can be decomposed according to the contribution of other endogenous variable, so as to explore which variable has the greatest impact on it. The results of variance decomposition in the fifth phase of VAR model are shown in Table 6 . It can be seen that nearly $100 \%$ of forecast variance in China stock returns comes from itself, while other markets have little influence on it. For the ASEAN-5 countries, besides themselves, China has the biggest influence on Malaysia, Singapore and Indonesia. 


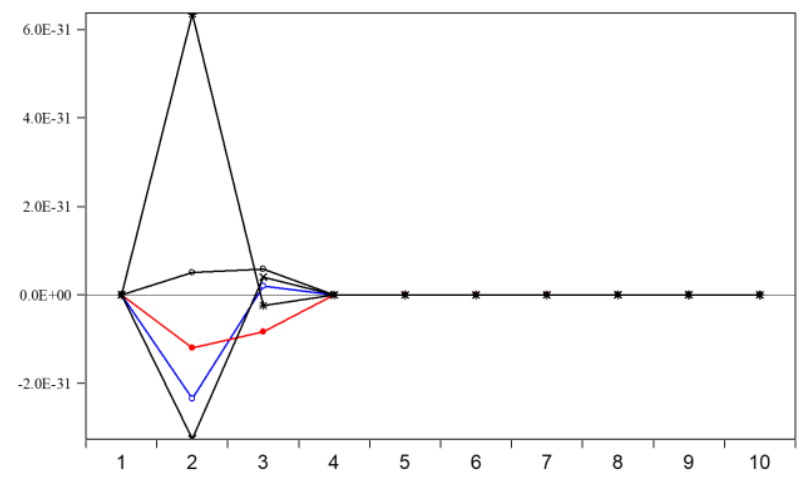

Figure 2 Response of RCSI to ASEAN-5 stock returns.

Based on the VAR model and the measurement of short-term mean spillover effects, the stock market correlation between China and Malaysia, Singapore as well as Indonesia is relatively close, proven by the results of Granger causality test, impulse response analysis and variance decomposition. Conversely, the mean spillover effect between China and Thailand as well as the Philippines are weak.

Table 6. Variance decompositions results of stock returns

\begin{tabular}{|l|l|l|l|l|l|l|}
\hline & RCSI & RMSM & RMSS & RPSI & RSET & RISE \\
\hline \multirow{2}{*}{ RCSI } & 100.00 & $1.57 \mathrm{E}-$ & $4.42 \mathrm{E}-$ & $2.99 \mathrm{E}-$ & $7.93 \mathrm{E}-$ & $4.09 \mathrm{E}-$ \\
& 00 & 30 & 31 & 29 & 30 & 30 \\
\hline RMS & 33.615 & 66.304 & $3.64 \mathrm{E}-$ & $1.37 \mathrm{E}-$ & $3.01 \mathrm{E}-$ & 0.0802 \\
M & 55 & 19 & 32 & 30 & 31 & 53 \\
\hline RMS & 22.011 & 11.212 & 0.8285 & 57.108 & $5.06 \mathrm{E}-$ & 8.8398 \\
S & 50 & 02 & 59 & 11 & 30 & 10 \\
\hline \multirow{2}{*}{ RPSI } & 2.9614 & 0.1592 & 91.140 & $1.03 \mathrm{E}-$ & $1.15 \mathrm{E}-$ & 5.7392 \\
& 52 & 27 & 06 & 30 & 31 & 66 \\
\hline \multirow{2}{*}{ RSET } & 0.5515 & 1.3129 & 1.4228 & 25.638 & 68.955 & 2.1186 \\
& 22 & 82 & 43 & 21 & 77 & 75 \\
\hline \multirow{2}{*}{ RISE } & 0.0328 & $2.60 \mathrm{E}-$ & $1.70 \mathrm{E}-$ & $7.06 \mathrm{E}-$ & $1.94 \mathrm{E}-$ & 99.967 \\
& 98 & 31 & 30 & 31 & 31 & 10 \\
\hline
\end{tabular}

\subsection{Mean Spillover Effect Analysis}

The stock returns generally are characterized by volatility cluster, that is the large changes follow the large one while the small changes follow the small one.[7] The volatility can be used to measure the risk of one stock market, and the risk may be contagious among the stock markets, which are defined as volatility spillover effect. Therefore, based on information criteria and autocorrelation results, this paper constructs GARCH $(1,1)$ model for the stock returns with the GARCH term representing the volatility of variance. Granger causality test is carried out for GARCH term, which is shown in Table 7.

As can be seen from the table above, the volatility spillover effect is significant, as all the spillover effect among the ASEAN-5 countries are two-way. Stock market volatility in Malaysia and Thailand will be transmitted to China and that in China will be transmitted to Singapore, there being no mutual volatility spillover effect for China.

Table 7. Granger causality test results of stock returns GARCH term

\begin{tabular}{|c|c|c|c|}
\hline \multicolumn{2}{|l|}{ Null Hypothesis } & \multirow{2}{*}{$\frac{\text { F-Statistic }}{1.80790}$} & \multirow{2}{*}{$\begin{array}{l}\text { Prob. } \\
0.1643\end{array}$} \\
\hline \multirow{5}{*}{ GARCH(RCSI) does not Granger Cause: } & GARCH(RMSM) & & \\
\hline & GARCH(RMSS) & 3.13157 & 0.0439 \\
\hline & GARCH(RPSI) & 0.65290 & 0.5207 \\
\hline & GARCH(RSET) & 0.79185 & 0.4532 \\
\hline & GARCH(RISE) & 0.92520 & 0.3967 \\
\hline \multirow{5}{*}{ GARCH(RMSM) does not Granger Cause: } & GARCH(RCSI) & 2.98780 & 0.0407 \\
\hline & GARCH(RMSS) & 337.623 & 0.0000 \\
\hline & GARCH(RPSI) & 3.03095 & 0.0485 \\
\hline & GARCH(RSET) & 14.6075 & 0.0000 \\
\hline & GARCH(RISE) & 174.897 & 0.0000 \\
\hline \multirow{5}{*}{ GARCH(RMSS) does not Granger Cause: } & GARCH(RCSI) & 1.92003 & 0.1469 \\
\hline & GARCH(RMSM) & 55.4818 & 0.0000 \\
\hline & GARCH(RPSI) & 10.0137 & 0.0000 \\
\hline & GARCH(RSET) & 29.1060 & 0.0000 \\
\hline & GARCH(RISE) & 45.2914 & 0.0000 \\
\hline GARCH(RPSI) does not Granger Cause: & GARCH(RCSI) & 2.55924 & 0.0777 \\
\hline
\end{tabular}




\begin{tabular}{|l|l|l|l|}
\hline \multirow{5}{*}{ GARCH(RSET) does not Granger Cause: } & GARCH(RMSM) & 81.7580 & 0.0000 \\
\cline { 2 - 4 } & GARCH(RMSS) & 41.3078 & 0.0000 \\
\cline { 2 - 3 } & GARCH(RSET) & 182.216 & 0.0000 \\
\cline { 2 - 3 } & GARCH(RISE) & 71.2239 & 0.0000 \\
\hline \multirow{5}{*}{ GARCH(RISE) does not Granger Cause: } & GARCH(RCSI) & 9.11045 & 0.0001 \\
\cline { 2 - 3 } & GARCH(RMSM) & 126.240 & 0.0000 \\
\cline { 2 - 3 } & GARCH(RMSS) & 105.108 & 0.0000 \\
\cline { 2 - 3 } & GARCH(RPSI) & 1.59705 & 0.0028 \\
\cline { 2 - 3 } & GARCH(RISE) & 191.694 & 0.0000 \\
\hline & GARCH(RCSI) & 0.87972 & 0.4151 \\
\cline { 2 - 3 } & GARCH(RMSM) & 11.4682 & 0.0000 \\
\cline { 2 - 3 } & GARCH(RMSS) & 18.4741 & 0.0000 \\
\cline { 2 - 3 } & GARCH(RPSI) & 0.48466 & 0.6160 \\
\cline { 2 - 3 } & GARCH(RSET) & 5.80171 & 0.0031 \\
\hline
\end{tabular}

\section{CONCLUSION}

In conclusion, the stock markets co-movement and spillover effects among China and ASEAN-5 countries are studied, using the representative stock indexes of each country. Firstly, there is no long-term equilibrium relationship among China and the ASEAN-5 countries, which may be caused by economic shocks. Secondly, through the VAR model, it is concluded that short-term mean spillover effect exists among China and ASEAN-5 stock markets. The Granger causality test shows that stock markets of Singapore, Thailand and Indonesia have a one-way influence on that of China, and other influencing paths among the ASEAN-5 countries are also one-way, instead of a two-way causal relationship. In the impulse response analysis, China stock market has strong response to the shocks from the Philippines, Thailand and Indonesia. The results of variance decomposition show that China's variance fluctuation is completely from itself. However, in Malaysia, Singapore and Indonesia, China's variance fluctuation can partly explain their changes in stock markets besides themselves. Thirdly, from the perspective of GARCH model, the volatility spillover effect China and ASEAN-5 countries stock market is significant. The turbulence in the stock markets of Malaysia and Thailand will pass to China, while China will pass to Singapore. There are mutual spillover effects among the ASEAN-5 countries.

The empirical results reveal that capital markets of China and ASEAN-5 countries are closely linked, which means the financial risks may be transmitted from other countries to China. Consequently, it is virtual for the Chinese authorities to be vigilant about the external risk, especially Singapore and Malaysia. However, with the development of economic integration and financial globalization, correlation of capital markets is inevitable. Thus, cooperation with neighbouring countries should be strengthened for China and ASEAN countries, to jointly cope with the regional financial risks and to speed up the progress of China-ASEAN stock market integration.

\section{REFERENCES}

[1] H. H. Lean, R. Smyth, Stock Market Co-movement in ASEAN and China. Emerging Markets and the Global Economy, 2014, pp. 603-622.

[2] T. T. Kee, H. Y. Siew, Y. C. Soo, H. L. Hooi, Financial Market Integration of ASEAN-5 with China and India-chapter 35. Emerging Markets and the Global Economy, 2014, pp. 825-859.

[3] N. Li, G. Li, Analysis on the Correlation of Stock Markets between China and Five Countries in Asia-Pacific Economic Circle. Economic Forum, 2011, vol. 12, pp. 98-101.

[4] N. Li, The Trends and Influencing Factors of the Synchronization of Economic Cycles between China, Japan, the United States and ASEAN. Guangxi Social Science, 2016, vol. 10, pp. 36-40.

[5] X. Cai, X. H. Li, Research on the Dynamic Convergence of China-ASEAN Stock Market under the Background of RMB Internationalization. Research on Finance and Economics, 2019, pp. 2.

[6] M. Dooley, M. Hutchison, Transmission of the US Subprime Crisis to Emerging Markets: Evidence on the Decoupling-Recoupling Hypothesis. Journal of International Money and Finance, 2009, pp. 1221-1349.

[7] J.Beirne, G. M. Caporale, G. Schulze, Global and Regional Spillover in Emerging Stock Markets: a Multivariate GARCH-in-mean Analysis. Emerging Markets Review, 2010, pp. 250-260. 